\title{
RESUME PEMBUATAN PROGRAM APLIKASI BORLAND DELPHI 7.0 BERBASIS PAPERPLAIN
}

\author{
Nama Mahasiswa \\ 143010012 \\ Universitas Mitra Indonesia, Sistem Informasi \\ Mahasiswa@umitra.ac.id

\begin{abstract}
Abstrak
Penjelasan Singkat Mengenai Isi File ini
\end{abstract}

\section{Noted :}

Tahap 1 ( Buatlah Account ) www.osf.io menggunakan domain email @ umitra.ac.id

Tahap 2 ( Upload Tugas Article (.pdf) Anda Pada OSF Preprints ), ikuti format dan Referensi Tidak Boleh Ditambah dan Diubah karena sudah disesuaikan, Lalu Link Dikirimkan Ke Wa Grup.

Tahap 3 Format Pengiriman Via WA Grup

NPM

Nama :

Judul :

Mata Kuliah :

Type : UAS Praktikum Struktur Data

Link OSF : 


\section{A. CAPTURE PROGRAM}

Melampirkan Capture program yang anda buat dengan Design Sendiri2 dan Tidak Copy Paste punya temannya

B. PENJELASAN

Penjelasan dari Software yang anda Buat.

C. DISKUSI

Pembahasan Permasalahan

\section{REFERENSI}

[1] A. S. Putra And O. M. Febriani, "Knowledge Management Online Application In Pdam Lampung Province," In Prosiding International Conference On Information Technology And Business (Icitb), 2018, Pp. 181-187.

[2] A. S. Putra, O. M. Febriani, And B. Bachry, "Implementasi Genetic Fuzzy System Untuk Mengidentifikasi Hasil Curian Kendaraan Bermotor Di Polda Lampung," J. Sist. Inf. Dan Manaj. Basis Data, Vol. 1, No. 1, Pp. 21-30, 2018.

[3] O. M. Febriani And A. S. Putra, "Sistem Informasi Monitoring Inventori Barang Pada Balai Riset Standardisasi Industri Bandar Lampung," J. Inform., Vol. 13, No. 1, Pp. 90-98, 2014.

[4] Putra, Arie Setya. "2018 Artikel Struktur Data, Audit Dan Jaringan Komputer." (2018).

[5] Putra, A. S. (2018, July 17). Paperplain Fundamental Create Application With Borland Delphi 7.0 University Of Mitra Indonesia. Retrieved From Osf.Io/Pbrn9. 